\title{
Comparative Analysis of Equity Financing Efficiency between Chinese and American New Energy Vehicle Listed Enterprises
}

\author{
$\mathrm{Mo} \mathrm{Li}^{1 *}$ \\ ${ }^{1}$ School of Mathematical Science, Loughborough University, Leicestershire, LE11 3TU, United Kingdom
}

\begin{abstract}
Under the dual pressure of global energy crisis and environmental problems, the exploration and application of new energy is an inevitable trend of economic development. Therefore, the development and research on equity financing efficiency of new energy vehicle listed companies appear to be of great value. From the perspective of equity financing efficiency, this paper explores the development status of new energy vehicle listed companies in the current era. Different from previous literature studies, we select China and the United States for comparative analysis and attempts to put forward strategic suggestions. Our paper adopts the DEA model, which is an equity financing efficiency evaluation model, to comprehensively evaluate the effectiveness of new energy listed enterprises, and then compares the equity financing efficiency of Chinese and American enterprises. Later, suggestions are provided on how to optimize the equity financing efficiency and development of new energy vehicle listed enterprises in China according to the found problems and conclusions.
\end{abstract}

\section{INTRODUCTION}

After attending the World Climate Conference in Copenhagen in 2009, countries around the world agreed to develop a low-carbon economy and reduce oil consumption to improve our living environment. Hence, the most urgent thing is to discover new energy sources that not only could replace traditional energy sources but also could protect the environment. Thus it could be seen that the exploration and application of new energy is also a key factor for countries to enhance their international competitiveness. With the huge friction between the development of automobile industry and environmental protection, governments agree on taking the construction of new energy automobile industry as an optimal solution to alleviate this contradiction. As a significant application of new energy, the United States, Japan, the United Kingdom and the European Union have promoted the development of new energy automobile industry to the level of national strategy. In terms of different technological advantages, each country has developed corresponding national strategy and independent research and development system based on the automobile market demand. Among them, the United States has already studied and developed new energy vehicles during the Clinton administration, and has accumulated a large amount of valuable literature and practical experience, which is of great reference significance for China. The Pew Foundation of the United States (2010) pointed out that from 2005 to 2009, countries all over the world invested heavily in clean energy projects and actively innovated in the field of high and new technology, among which the United States, Japan and organizations of the European Union developed rapidly. Actually, Green et al. (2013) argued that the efficiency of the American automobile industry was also slightly low, but the technological innovation gap between China and the United States would hinder the improvement and development of the efficiency of China's new energy automobile industry $(\mathrm{Li}, 2012)$.Wen and Tang(2014) proved that the efficiency of resource allocation in China's scientific and technological innovation is relatively low.

From the current situation, the main problem faced by the listed companies of new energy vehicles is the capital efficiency of the listed companies. Can this problem be better analyzed from the perspective of equity financing efficiency? What are the differences between China and the United States?

\subsection{The Definition of New Energy Vehicles}

Compared with the traditional fuel vehicles, new energy vehicles refer to the use of unconventional source of power as the driving force cars, with a new structure and new technology, rather than general materials, such as diesel and gasoline. Broadly speaking, it covers all the new vehicles, new energy vehicles in the case of conventional fuel power plant using the new on-board power unit, which has the latest structure, technology and also production.

*Corresponding Author`s Email: 986146931@qq.com 


\subsection{Research Significance and Objectives}

The new energy automobile industry is an important direction for China to realize sustainable development in the future. Meanwhile, the new energy automobile industry is characterized by strong innovation, large growth space and high industry risk, which demands continuous capital inflow and perfect risk guarantee system support. While the 'subsidy fraud' event occurred fluently under the strong support of national policies in the early stage of industry development. According to the decrease of government subsidies year by year, the profits of new energy vehicle listed enterprises decreased, leading to the decline of internal financing. It is no doubt that financing ability is the core point for any enterprise to survive in the growth period. Therefore, the decline of internal financing could be made up by improving the efficiency of equity financing. Equity financing, as the main financing approach for new energy vehicle listed companies, has important research value. It is also of great significance to improve equity financing efficiency and allocation efficiency to perfect the financial market. In order to make finance better promote the real economy, in consideration of equity preference, improving equity financing efficiency is the key to promoting the good development of new energy vehicle listed companies in the future. Several scholars at home and abroad have done abundant research on financing efficiency, which has laid a solid foundation for followup research. However, domestic and foreign scholars focus on the Growth Enterprise Board and the New Third Board, and their preference for the industry is mostly concentrated in high-tech fields, while few scholars pay attention to the field of new energy vehicles. In addition, there is a lack of research on equity financing efficiency in China and the United States, which is helpful for investors to understand the equity financing situation of the industry and carry out reasonable equity financing.

Therefore, this paper takes equity financing efficiency of new energy vehicle listed companies as the research object, conducts comparative analysis from the perspectives of China and the United States, and starts with factors affecting equity financing efficiency, through establishing the equity financing efficiency evaluation model, validating the equity financing efficiency of Chinese and American new energy vehicle listed enterprises. Then the DEA model is used for empirical analysis. Finally, the problem reflected by the empirical results is that the overall financing scale of China's new energy automobile industry is good, but the technical efficiency is low compared with that of the United States. At the same time, the development of management and technical level is the core factor to improve the equity financing efficiency of China's new energy automobile listed companies.From the perspective of enterprises and the government, this paper puts forward some suggestions on the optimization of the new energy automobile industry, such as optimizing the internal shareholding structure, improving the level of core technology and strengthening the government subsidy policy, so as to make certain contributions to the sustainable development of the new energy automobile listed companies.

\subsection{Paper Structure}

The rest of the paper is organized as follows. Section 2 summarizes the literature review of relevant knowledge, which includes development status of China and the United States, research on new energy vehicle listed enterprises, research on corporate financing and financing efficiency, research on equity financing efficiency factors and evaluation. Also gives a theory framework. Section 3 develops the complete empirical analysis process based on the data selection and DEA efficiency analysis. Then, the framework is extended to empirical results. Finally, Section 4 concludes the advice and presents direction for future research.

\section{LITERATURE REVIEW}

\subsection{Development status of New Energy Vehicles in China and the United States}

The research and development system in the US has been relatively mature. From the 'New Generation Automobile Cooperation Program' of the Clinton administration in 1993, to the 'Freedom Car Project' of George W. Bush, to the 'EV Everywhere' of the Obama administration, the US government has shown sufficient enthusiasm to develop the domestic new-energy automobile industry and try to get rid of the dependence on imported oil. Although China's new energy automobile industry started late compared with developed countries, there is a small gap between China and developed countries compared with traditional automobile manufacturing industry. Therefore, China clearly lists the new energy automobile industry as one of the ten key development industries made in China in 2025. Since 2017, the development momentum of China's new energy vehicles has gradually shifted from government-driven to market-driven, and its production and sales have ranked first in the world for four consecutive years. In 2018, 1.256 million new energy vehicles were sold. In 2019, the total sales volume of new energy vehicles nationwide was 1.206 million, although the decline was $3 \%$. However, the government pointed out that by 2025 , the competitiveness of new energy vehicles will be significantly improved, gradually forming a market competitive advantage. It's worth noting that the 2018 Global Electric Vehicle Development Index report released by Roland Berger shows that the U.S. electric vehicle development Index and China's electric vehicle development Index are tied for first place.

\subsection{Research on New Energy Vehicle Listed Enterprises}

The early high investment will bring higher barriers, which leads to trigger corporate financing constraints. 
Similarly, Ghosh (2006) found that a single financing channel also restricts corporate financing. It is worth noting that the government's venture capital has the most significant impact on the financing and development of new energy automobile enterprises (Fan and He, 2012), and the United States could improve the effectiveness of government policies by reducing market bias (Green et.al, 2014). Moreover, Yu et al. (2015) pointed out that the fiscal and tax regulation policies of China's new energy automobile industry are inferior to those of the United States. Liu and Li (2016) put forward a feasible proposal for China to learn from the California Government of the United States to launch the new energy vehicle point-scoring policy. And Liao (2017) further classified the fiscal and tax policies of new energy vehicles and looked for how fiscal and tax policies promoted the development of new energy vehicles industry.

To sum up, there is a lack of specific efficiency analysis and a lack of comparative analysis between China and the United States in the current research on new energy listed companies.

\subsection{Research on Corporate Financing and Financing Efficiency}

In western literature, the concept of corporate financing efficiency hardly exists, which may have a great relationship with the existing property organization system or property right system in the west, but its abundant theoretical research has laid a foundation for the study of financing efficiency. For example, Pareto proposed the concept of efficiency and at the same time proposed the important Pareto optimal theory to measure the efficiency of capital allocation (Chari, 2002). The MM theorem proposed by Modigliani and Miller (1958) laid the foundation for the study of modern enterprise financing efficiency. In the field of equity financing, corporate governance has a significant negative impact on the cost of equity financing (Campello et al., 2002), but the profitability of an enterprise is positively correlated with its equity financing capability (Giles et al., 2010). Besides, Wilton et al. (2014) found that the amount of equity financing of an enterprise would have an impact on the financing efficiency.

In contrast, domestic scholars are more interested in studying the impact on the financing efficiency of Chinese enterprises. In 1993, Zeng Kanglin, a Chinese scholar, first put forward the concept of 'financing efficiency'. Song (1997) pointed out earlier that the concept of efficiency in economics refers to the relationship between costs and benefits, Wen (1999) and Qi (2013) also put forward similar views. On this basis, Zheng (2004) pointed out that Chinese enterprises attach great importance to equity financing, but it is generally inefficient. Huang et al. (2018) found that the capital obtained from equity financing is not required to repay principal and interest, which is popular among many domestic enterprises, thus prompting a large number of domestic scholars to explore the efficiency of equity financing. Also, Xiao and Guo (2018) found that technological progress was most conducive to the improvement of equity financing efficiency.

\subsection{Research on Equity Financing Efficiency Factors and Evaluation}

In view of the listed company equity financing efficiency measurement involving more indicators, it is a complicated multiple input and multiple output model. Traditional evaluation methods are generally based on optimization principle and satisficing principle, such as fuzzy evaluation (Pang, 2013), normative analysis method (Li, 2012) and entropy weight coefficient method (Li, 2006). These methods need to determine the priority weight of each index, and the determination of weight is often difficult to avoid subjectivity. Meanwhile, the difference in importance between different evaluation objects will also lead to the non-impartiality of evaluation. Significantly, Data Envelopment Analysis (DEA), which was proposed by Charnes, Cooper and Rhodes in 1987, is a commonly used Analysis method in the field of operations research and has become a relatively effective method to evaluate equity financing efficiency at present. When using DEA model, multiple input indicators can be selected for multiple output indicators, and it is necessary to establish the enterprise productivity optimization model. Then whether the ratio of input to output is 1 can be used to judge whether the equity financing efficiency of enterprises is effective, which is consistent with the definition of equity financing efficiency in this paper. Therefore, the DEA model is selected in this paper as the evaluation method for the equity financing efficiency of listed enterprises of new energy vehicles in China.

\subsection{Theoretical framework}

The new energy automobile industry is an important direction for China to realize sustainable development. In fact, the decline of government subsidies has raised the production costs and compressed profit margins of new energy vehicles listed companies, resulting in reducing retained earnings and the proportion of internal financing. Therefore, the efficiency of external financing, especially equity financing, becomes very critical. As summarized in 2.4, compared with other efficiency evaluation methods, DEA model could overcome the subjectivity in index weight design and provide improvement schemes for enterprises that fail to achieve technical efficiency.

As shown in Figure 1, the DEA model is adopted in this paper to measure the efficiency index, then DEA efficiency analysis, scale return analysis and efficiency mean value analysis are respectively carried out. First, according to the results of the model, three important efficiencies of new-energy vehicle listed companies in China and the United States in the past five years are analyzed.The new energy automobile industry is booming, and the scale benefit of enterprises is worth further subdivision and discussion, so as to put forward guiding opinions on the scale of enterprises.Among them, 
the scale situation is divided into increasing returns to scale, diminishing returns to scale and diminishing returns to scale. Then, the mean value can be used to further confirm the analysis results and give a comprehensive conclusion.

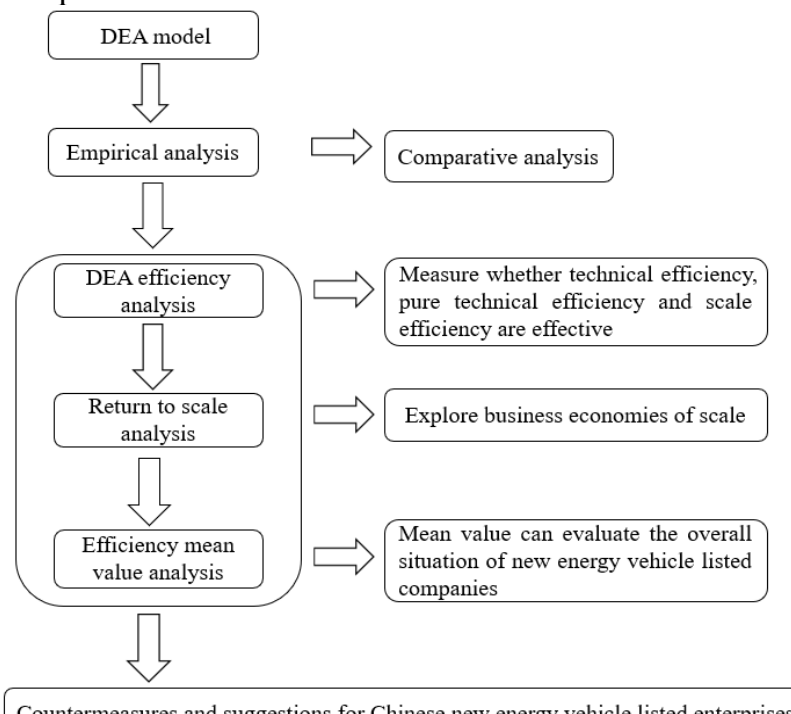

Figure 1 Analysis path of equity financing efficiency of new energy vehicle listed enterprises

Source of Figure 1 by the author.

\section{EMPIRICAL ANALYSIS}

This chapter will focus on the empirical analysis of equity financing efficiency of new energy vehicle listed companies in China and the United States. DEAP2.1 software was used to solve the DEA model of financing efficiency. According to the research results, the efficiency analysis was carried out respectively from 2015 to 2019, and the conclusions were finally drawn.

\subsection{Data Selection}

In order to ensure the accuracy of data, missing data and ST stocks are eliminated on the premise of DEA model operation. In this paper, 70 representative new energy listed enterprises are selected, among which 31 are from the United States and 39 from China. Later collect all the data of six financial indicators of each company in the five years from 2015 to 2019 for calculation so as to compare and study the equity financing efficiency of listed Chinese and American new energy companies. All the original data is from the Wind information database data and the annual report data of each enterprise.

Liu et al. (2004) used total equity financing, equity concentration, asset-liability ratio as input indicators, roe as main operating income growth rate, and Tobin's $Q$ value as output indicators to comprehensively evaluate the equity financing efficiency in China. Xiong et al. (2014) used DEA method to select the total amount of equity financing, operating cost as the input index, return on equity, growth rate of operating revenue, and Tobin's $Q$ value as the output index. Subsequently, in consideration of the desirability of the subject and data, six financial indicators will be used in this paper, including the total market value of the issue (Jiang and Ma, 2017), equity concentration, operating cost as input indicators, return on equity, growth rate of operating income, and earnings per share (Xiao and Guo, 2018) as output indicators.

To sum up, establish the following input-output index system related to equity financing efficiency:

1. Total market value: the amount of capital raised by a listed company through equity financing. It refers to the total amount of capital stock multiplied by the stock price at that time.

2. Ownership concentration degree: the ownership concentration degree is represented by the shareholding ratio of the largest shareholder, and the strength of the equity distribution and stability of the enterprise is evaluated.

3. Operating cost: when the revenue is fixed, the higher the operating cost, the lower the profit of the enterprise. The level of profit represents the capital use efficiency of the enterprise.

4. Return on equity: return on equity $=$ net profit/net asset, reflecting the financial benefits and profitability of listed companies after equity financing.

5. Growth rate of operating income: increase of operating income of the current year/total operating income of the previous year. The output index can reflect the support degree of equity financing funds to the growth of operating income.

6. Earnings per share: after tax profit/total share capital. The ratio reflects the positive effect of equity financing funds on the profitability of enterprises. The higher the ratio, the stronger the market performance of the enterprise.

\subsection{DEA Efficiency Analysis Results analysis}

\subsubsection{DEA efficiency analysis}

When DEA efficiency is 1 , it indicates that enterprise capital has been reasonably applied and financing is effective, and there is no excess input or insufficient output to achieve the optimal input and output effect. At the same time, its pure technical efficiency and return to scale efficiency also reached the most effective state, under the premise of constant return to scale, the current input also reached the maximum output effect. Conversely, when efficiency is less than 1 , it is not effective.

Table 1 DEA model results in U.S.

\begin{tabular}{|c|c|c|c|c|c|c|c|}
\hline \multicolumn{2}{|c|}{$\begin{array}{c}\text { U.S. } \\
\text { (total } 31 \text { companies) }\end{array}$} & \multicolumn{2}{|c|}{ Technical Efficiency } & \multicolumn{2}{|c|}{$\begin{array}{l}\text { Pure Technical } \\
\text { Efficiency }\end{array}$} & \multicolumn{2}{|c|}{ Scale Efficiency } \\
\hline \multirow[t]{2}{*}{2015} & effective & 5 & \multirow[t]{2}{*}{$16 \%$ effective } & 7 & \multirow[t]{2}{*}{$22 \%$ effective } & 5 & \multirow[t]{2}{*}{$16 \%$ effective } \\
\hline & ineffective & 26 & & 24 & & 26 & \\
\hline \multirow[t]{2}{*}{2016} & effective & 10 & \multirow[t]{2}{*}{$32 \%$ effective } & 14 & \multirow[t]{2}{*}{ 45\% effective } & 10 & \multirow[t]{2}{*}{$32 \%$ effective } \\
\hline & ineffective & 21 & & 17 & & 21 & \\
\hline \multirow[t]{2}{*}{2017} & effective & 13 & \multirow[t]{2}{*}{$42 \%$ effective } & 18 & \multirow[t]{2}{*}{ 58\% effective } & 13 & \multirow[t]{2}{*}{$42 \%$ effective } \\
\hline & ineffective & 18 & & 13 & & 18 & \\
\hline \multirow[t]{2}{*}{2018} & effective & 12 & \multirow[t]{2}{*}{ 39\% effective } & 20 & \multirow[t]{2}{*}{ 65\% effective } & 12 & \multirow[t]{2}{*}{$39 \%$ effective } \\
\hline & ineffective & 19 & & 11 & & 19 & \\
\hline \multirow[t]{2}{*}{2019} & effective & 10 & \multirow[t]{2}{*}{$32 \%$ effective } & 14 & \multirow[t]{2}{*}{ 45\% effective } & 10 & \multirow[t]{2}{*}{$32 \%$ effective } \\
\hline & ineffective & 21 & & 17 & & 21 & \\
\hline
\end{tabular}


Source of table 1 by the author. From table 1, it can be seen that from 2015 to 2018, the equity financing efficiency of listed companies of new energy vehicles in the United States has been steadily improving. It has the best performance in 2018 . Among the 31 listed companies in the United States, 12 listed companies have effective equity financing efficiency with DEA under constant return on scale, but it only accounts for $39 \%$. The technical efficiency of $39 \%$ enterprises is 1 , and the value of the relaxation variable of input and output is 0 , that is, the input and output are exactly matched, there is no input redundancy and output shortage, and the maximum output can be obtained with the minimum input, achieving DEA efficiency of listed companies. Furthermore, there are 20 companies, that is, $65 \%$ of the companies in the sample, whose pure technical efficiency reaches 1 under the variable scale return, and the value of the relaxation variable is 0 , reaching DEA efficiency, which is $26 \%$ higher than that in the variable scale return model. However, the equity financing efficiency of the listed companies of new energy vehicles in the United States in 2019 declined compared with the previous year. Despite the decline, the overall data of 2019 is still in a good state.

Table 2 DEA model results in China

\begin{tabular}{|c|c|c|c|c|c|c|c|}
\hline \multicolumn{2}{|c|}{$\begin{array}{l}\text { China } \\
\text { (total } 39 \text { companies) }\end{array}$} & \multicolumn{2}{|c|}{ Technical Efficiency } & \multicolumn{2}{|c|}{$\begin{array}{l}\text { Pure Technical } \\
\text { Efficiency }\end{array}$} & \multicolumn{2}{|c|}{ Scale Efficiency } \\
\hline \multirow[t]{2}{*}{2015} & effective & 7 & \multirow[t]{2}{*}{$18 \%$ effective } & 12 & \multirow[t]{2}{*}{$31 \%$ effective } & 7 & \multirow[t]{2}{*}{ 18\% effective } \\
\hline & ineffective & 32 & & 27 & & 32 & \\
\hline \multirow[t]{2}{*}{2016} & effective & 12 & \multirow[t]{2}{*}{$31 \%$ effective } & 17 & \multirow[t]{2}{*}{ 44\% effective } & 12 & \multirow[t]{2}{*}{$31 \%$ effective } \\
\hline & ineffective & 27 & & 22 & & 27 & \\
\hline \multirow[t]{2}{*}{2017} & effective & 11 & \multirow[t]{2}{*}{$28 \%$ effective } & 18 & \multirow[t]{2}{*}{$46 \%$ effective } & 12 & \multirow[t]{2}{*}{$31 \%$ effective } \\
\hline & ineffective & 28 & & 21 & & 27 & \\
\hline \multirow[t]{2}{*}{2018} & effective & 9 & \multirow[t]{2}{*}{$23 \%$ effective } & 17 & \multirow[t]{2}{*}{$44 \%$ effective } & 9 & \multirow[t]{2}{*}{ 23\% effective } \\
\hline & ineffective & 30 & & 22 & & 30 & \\
\hline \multirow[t]{2}{*}{2019} & effective & 10 & \multirow[t]{2}{*}{$26 \%$ effective } & 14 & \multirow[t]{2}{*}{$36 \%$ effective } & 11 & \multirow[t]{2}{*}{$28 \%$ effective } \\
\hline & ineffective & 29 & & 25 & & 28 & \\
\hline
\end{tabular}

Source of table 2 by the author.

Based on table 2, China's new energy vehicle listed companies are in a flat growth stage from 2015 to 2017. It can be seen that comprehensive technical efficiency and pure technical efficiency grow faster. In 2015, the new energy automotive industry began to pay more attention to the development of core technology and enterprise management. Enterprises that lose competitiveness are eliminated by the market, while relatively better enterprises are favored by investors. Therefore, equity financing efficiency of new energy vehicle listed enterprises has improved in 2016 and 2017. In 2018 and 2019, there was a slight downward trend, mainly due to the slowdown of domestic macroeconomic growth and the failure of many enterprises to achieve economies of scale, resulting in the failure of comprehensive efficiency of most enterprises that have achieved enterprise management and technology efficiency. After the rapid growth from 2015 to 2017, under the market competition mechanism, small or poorly managed enterprises are gradually exposed, and investors are more sober and rational, which increases the cost of equity financing for new energy vehicle listed companies and reduces the efficiency of equity financing.
In general, the DEA effective proportion of equity financing efficiency of China's new energy vehicle listed companies is low at present, and the non-effective proportion is still more than $60 \%$ until 2019 . As for the equity financing efficiency of new energy vehicle listed companies in the United States in 2019, the DEA effective ratio of equity financing efficiency is nearly $45 \%$ higher than that of China, which is nearly $36 \%$. Thus, it can be seen that the equity financing efficiency of listed companies in the United States is relatively high, and their integrated funds are reasonably and effectively used. Therefore, China's new energy listed companies need to improve the equity financing efficiency through further improvement compared with the United States.

\subsubsection{Return to scale analysis}

From the above two tables, we can know the scale efficiency of China and the United States, and then we will analyze the specific situation of scale reward in both countries from 2015 to 2019.

Table 3 Comparison results of Scale compensation between China and the United States

\begin{tabular}{|c|c|c|c|c|c|c|c|c|c|c|c|c|c|c|c|}
\hline & \multicolumn{3}{|c|}{2015} & \multicolumn{3}{|c|}{2016} & \multicolumn{3}{|c|}{2017} & \multicolumn{3}{|c|}{2018} & \multicolumn{3}{|c|}{2019} \\
\hline & Irs & Drs & - & Irs & Drs & - & Irs & Drs & - & Irs & Drs & - & Irs & Drs & - \\
\hline U.S. & 24 & 2 & 5 & 18 & 3 & 10 & 15 & 3 & 13 & 17 & 2 & 12 & 20 & 1 & 10 \\
\hline China & 25 & 7 & 7 & 19 & 8 & 12 & 22 & 5 & 12 & 21 & 6 & 9 & 20 & 8 & 11 \\
\hline
\end{tabular}

Source of table 3 by the author.

Note: '-' represents constant return to scale, 'DRS' represents diminishing return to scale, 'IRS' represents increasing return to scale, the numbers represent how many companies are in -/Irs/Drs

The table 3 makes it clear that America's overall performance is better than China's. In this case, the enterprise does not have the problem of redundant input and insufficient output. Therefore, the funds raised by the company will be managed and utilized reasonably and effectively. In 2019, there were 20 companies in both the US and China in the stage of increasing return on scale (IRS), indicating that enterprises should increase the proportion of input to get more output, and enterprises should increase the proportion of investment. One firm in America and eight in China are in the stage of diminishing returns to scale (DRS), in which increased inputs exceed increased outputs. Enterprises with diminishing returns to scale may be due to their limitations in production factors and low management efficiency, resulting in insufficient output of listed companies, low equity financing efficiency, and inputoutput mismatch of the company. Therefore, the scale should be reduced and the equity financing efficiency of listed companies should be improved.

\subsubsection{Efficiency mean value analysis}

By calculating the technical efficiency, pure technical efficiency and scale efficiency of 39 listed companies in China and 31 listed companies in the United States from 2015 to 2019, and then taking the mean value respectively, the average efficiency of China and the 
United States from 2015 to 2019 can be obtained. Next, it is necessary to carry out mean efficiency analysis for China and the United States.

Table 4 Results of mean efficiency between China and the United States

\begin{tabular}{|l|l|l|l|l|l|l|}
\hline Country & $\begin{array}{l}\text { Efficiency } \\
\text { Indicators }\end{array}$ & $\begin{array}{l}\text { The mean } \\
\text { of } 2015\end{array}$ & $\begin{array}{l}\text { The mean } \\
\text { of 2016 }\end{array}$ & $\begin{array}{l}\text { The mean } \\
\text { of 2017 }\end{array}$ & $\begin{array}{l}\text { The mean } \\
\text { of 2018 }\end{array}$ & $\begin{array}{l}\text { The mean } \\
\text { of 2019 }\end{array}$ \\
\hline \multirow{4}{*}{ U.S. } & TE & 0.662 & 0.869 & 0.913 & 0.887 & 0.806 \\
\cline { 2 - 7 } & PTE & 0.857 & 0.936 & 0.948 & 0.953 & 0.917 \\
\cline { 2 - 7 } & SE & 0.769 & 0.921 & 0.962 & 0.927 & 0.871 \\
\hline \multirow{3}{*}{ China } & TE & 0.754 & 0.821 & 0.719 & 0.806 & 0.812 \\
\cline { 2 - 7 } & PTE & 0.906 & 0.914 & 0.908 & 0.918 & 0.890 \\
\cline { 2 - 7 } & SE & 0.828 & 0.894 & 0.791 & 0.874 & 0.915 \\
\hline
\end{tabular}

Source of table 4 by the author.

Technical efficiency mainly investigates whether the listed enterprises of new energy vehicles have realized the optimal allocation of strategic resources. After decomposition, pure technical efficiency and scale efficiency are obtained, which respectively represent the production efficiency of enterprises affected by management level, technology and other factors and the production efficiency of enterprises affected by financial system scale factors. Among them, the comprehensive efficiency value of the US in 2017 and 2018 is as high as 0.913 and 0.887 , while that of China in 2019 is 0.812 , reaching a relatively effective state. This shows that compared with the United States, China is in a state of low comprehensive technical efficiency and low pure technical efficiency, and its financial support efficiency has not yet reached the maximum output or the optimal state of minimum input under the given output, failing to realize a good resource allocation. The United States has a better management system, technical level and operation mechanism than China, which better supports the development of new-energy automobile enterprises. China's slowness to update its technology has curbed its overall efficiency gains. Moreover, from 2016 to 2018, the scale efficiency of China was always lower than that of the United States. However, in 2019, the scale efficiency of China reached 0.915, indicating that China's financial resources are gradually exerting scale economy effect.

\subsection{Empirical Conclusions}

Using DEA model to analyze the new energy vehicles over the past five years, it could be concluded that the overall company efficiency of equity financing is in a state of steady rise due to the new energy boom. The technological efficiency of American enterprises reached $65 \%$ in 2018 , but the proportion of DEA efficiency in equity financing efficiency of Chinese new energy vehicle listed companies is low. In addition, it could be concluded that the equity financing efficiency of American new energy vehicles is superior to that of Chinese new energy vehicles from the perspective of return on scale and average efficiency.

\section{Conclusion and Prospect}

\subsection{Conclusion}

The following research conclusions are drawn.

The listed companies of new energy vehicles in China and the United States have been in the forward development stage from 2015 to 2019 , and the United States has been in the overall leading state, which is mainly reflected in the technology and management level of enterprises and government support.

From the perspective of decomposition indicators, the overall financing scale of China's new energy automobile industry is relatively good, but the technical efficiency is relatively low, indicating that most enterprises focus too much on improving the return on scale and neglect the importance of enterprise management and technology. First of all, pure technical efficiency further restricts the improvement of equity financing efficiency of listed enterprises of new energy vehicles in China, because the backward technology of enterprises leads to the decline of enterprise output, then affecting the use efficiency of financing funds, and thus affecting the equity financing efficiency of enterprises. Compared with the United States, China is short of hightech talents. What's more, the core components of enterprises lack technological breakthroughs. This is because the United States has the leading technology and vigorously introduces the world's advanced technical talents to activate the market and optimize the allocation of domestic resources, while Chinese enterprises do not pay attention to the cultivation of professional talents.

In addition, the ownership concentration is too high. Compared with the United States, the new energy listed companies in China are featured with 'single dominant share', and most of the largest shareholders hold more than $20 \%$, which leads to the problem of equity distribution in enterprise management, thus the internal structure of enterprises needs to be optimized.

Finally, China's current policy support is not enough, the government's subsidies are too small, is not enough to stimulate consumers' desire to buy. Only by reducing the burden of new-energy vehicle consumers on newenergy vehicles can the development of new-energy vehicle industry be promoted.

\subsection{Improve Measures}

\subsubsection{0ptimize the internal ownership structure of the enterprise}

The collected data of market value and equity concentration and efficiency show that moderate asset size and sound enterprise management can improve equity financing efficiency. The high degree of equity concentration is one of the important reasons for the low equity financing efficiency of new energy vehicle listed enterprises in China. Compared with the United States, the high concentration of equity weakens the corporate governance mechanism, especially the motivation of major shareholders to pursue the gains of their control 
rights at the expense of other shareholders. At the same time, the stock circulation is low, which can not effectively supervise the behavior of controlling shareholders and insiders. Therefore, it is necessary to optimize equity structure and improve equity financing efficiency. First, further realize the equilibrium of the stock market. Second, cultivate institutional investors with a control-oriented approach. Through the entry of institutional investors, the equity is properly dispersed, which is conducive to the operators to accept the supervision of diversified property rights subjects on a larger scale, so as to standardize the corporate governance structure and improve efficiency. Finally, the independent director system should be improved. Directly acting on the source of the company's internal control is conducive to improve the quality of the enterprise and improve the internal governance structure.

\subsubsection{Cultivate core competitiveness and enhance the technological level of enterprises}

The formation of core competitiveness is the key to the growth of listed enterprises. It is difficult to copy and imitate, has the potential to enter a variety of markets, and can achieve higher value than competitors, so as to ensure the sustainable development of enterprises. In the United States, new-energy vehicles have a good development platform, a strong industrial foundation and conditions, as well as relatively perfect policies and regulations support. It can be said that they occupy the right place at the right time. As a technology-oriented industrial cluster, the most important thing for the new energy automobile industry is to develop the scientific research technology of enterprises. As a technologybased industry, enterprises with independent research and development technology are one of the most important competitiveness of enterprises in the market. However, China's upstream support industry core technology has not yet broken through, security cannot be guaranteed, high cost, leading to the downstream new energy vehicle technology, safety and cost problems. It is necessary to pay full attention to the role of industrial technology innovation alliance and public technology platform, realize the common technology sharing and intensive technology innovation at the minimum cost, give play to the effective connection of information among various enterprises, and promote the industrialization process of new energy vehicles.

From the empirical evaluation results of equity financing, the management and technical level of enterprises have an important impact on the efficiency of equity financing. Therefore, Chinese new-energy automobile enterprises should pay more attention to the development of production technology, subdivide production through market demand, establish research and development department of special technology, introduce excellent talents and technologies at home and abroad, and encourage product innovation, so as to promote industrial upgrading and improve equity financing efficiency of enterprises. Therefore, it is necessary to strengthen the allocation efficiency of funds in guiding the construction of talent teams and technological innovation, strengthen the training and introduction of new energy automobile professionals, intensify the independent research and development of core technologies, and break through the reverse impact of technological restrictions on the financing efficiency of new energy automobile industry, so as to achieve technological progress leading to progress.

\subsubsection{Strengthen government subsidy policies and industry guidance}

In view of the development of China's automobile industry, the government should implement reasonable subsidy policies to stimulate consumption, which will be a new starting point for the development of China's new energy vehicles. Due to the subsidy fraud incident and the new energy automobile industry market will gradually transform from government-led to market-led. In order to ensure the sustainable development of the new energy automobile industry, the government needs to introduce more reasonable subsidy policies. First, the government can raise the subsidy threshold to guide new-energy automobile enterprises to develop independently and prevent the occurrence of subsidy fraud. For example: to have the technical content production enterprise carries on the subsidy. Second, the government can implement consumption subsidies to stimulate new energy automobile enterprises to form industrialization and expand their scale through the market demand for products.

In addition, the government should give full play to the role of publicity and guidance. The United States is one of the major consumers of new energy vehicles, and the concept of green and environmental protection has been deeply rooted in American consumers. The consumption concept is an important factor that makes new energy vehicles sell well in the United States. Comparatively speaking, China has the largest potential consumption market of new energy vehicles, and strengthening publicity is also one of the important means to promote the development of listed enterprises of new energy vehicles and improve the efficiency of equity financing. The government should take green, environmental protection and health as the orientation, encourage consumers to set up corresponding consumption concepts, and guide the whole people to attach importance to new energy vehicles. In short, there is an urgent need to expand the coverage of government policies, strengthen resource integration in national innovation demonstration projects and take a long-term view.

\subsection{Research Outlook}

This paper has two advantages. On the one hand, the new energy automobile industry has been a hot industry in recent years. Most of the literature focuses on the financing research of the new energy automobile industry, while there is little equity financing efficiency, let alone a comparative analysis between China and the 
United States, so as to put forward targeted Suggestions and optimize the equity financing efficiency of China's new energy automobile listed companies. On the other hand, most literature uses the DEA model to evaluate and analyze the equity financing efficiency of enterprises, where input index data is only selected for one year, and output index is the average value of several years. In this paper, the data of each year from 2015 to 2019 are all selected, so as to have a clearer understanding of the changes in equity financing efficiency of China and the United States new-energy vehicle listed companies in the past five years and make a comparative analysis. Nevertheless, the paper focuses more on the micro aspects of enterprises in the selection of input and output indicators, relatively ignoring the specific impact of macro factors on enterprises, and also does not make an empirical analysis of the impact factors of equity financing. What is more, some suggestions are put forward to optimize the structure of equity financing. It is necessary to do further research on equity allocation.

To sum up, in the face of the opportunities brought by new energy vehicles to the automobile industry, governments, enterprises and other forces around the world have stepped on the stage and started a huge competition. China and the United States are also busy planning the layout of new energy vehicles, and striving to take the lead in the development and industrialization of new energy vehicles. The energy crisis provides an opportunity for the development of new energy, and new energy vehicles emerge at the historic moment, which is not only an opportunity for enterprises and industries, but also a national strategic opportunity. How to improve the equity financing efficiency of new energy vehicle listed companies is an important topic for further research. It is hoped that in future research, the above deficiencies can be improved, the depth and breadth of the research can be improved, and better theoretical support and solutions can be provided for further improving the equity financing efficiency of new energy vehicle listed enterprises.

\section{REFERENCES}

1. Balakrishnan, K., Core, J. E., and Verdi, R. S., 2014. The relation between reporting quality and financing and investment: Evidence from changes in financing capacity. Journal of Accounting Research, 52(1), pp.1-36.

2. Campello, Murillo, Ashcraft, and Adam B.,2002. Borrowers' Financial Constraints and the Transmission of Monetary Policy: Evidence from Financial Conglomerates. Social Science Electronic Publishing, (6), p.79.

3. Chari, A. and Henry, P. B., 2002. Capital Account Liberalization: Allocative Efficiency or Animal Spirits? National Bureau of Economic Research, (No. w8908).

4. Fan, C. and He, Y., 2012. Some countries support the financing mode of new energy enterprises for reference. Economic review, (2), pp.114-116.
5. Ghosh, A., 2006. The IPO phenomenon in the 1990s. The Social Science Journal, (4), p.19.

6. Giles, David E, Ni, Yang, Guo, and Shasha.,2010. Capital structures in an emerging market: a duration analysis of the time interval between IPO and SEO in China. Applied Financial Economics, (5), p52.

7. Green, E. H., Skerlos, S. J., and Winebrake, J. J., 2014. Increasing electric vehicle policy efficiency and effectiveness by reducing mainstream market bias. Energy Policy, 65(3), pp.562-566.

8. Huang, Y. and Zhang, M., 2018. Review of equity financing efficiency. Entrepreneurship and economic development, (6), pp.45-48.

9. Jiang, X. and Ma, J., 2017. Equity financing efficiency and influencing factors of water industry listed companies. Water Economy, (3), pp.26-30.

10. Li, D., 2007. Research On Financing Efficiency Of Listed Companies In Heilongjiang Province. Undergraduate. Harbin Engineering University.

11. Li, K., 2012. Improvement of new energy vehicle industry chain from the perspective of regional innovation. Economic Forum, (09), pp.131-132.

12. Liao, J. and Sun, X., 2017. Research on the effect of fiscal and tax policies for new energy vehicles. Taxation and economy, (01), pp.86-93.

13. Liu, H. and Li, J., 2016. Enlightenment of "new energy integration policy" of the United States to China. Automotive Industry Research, 07, pp.19-21.

14. Liu, L., Feng, G. and Zhang, D., 2004. Evaluation of equity financing efficiency of listed companies based on DEA. Systems Engineering, (1), pp.55-59.

15. Modigliani, F., and Miller, M. H., 1958. The cost of capital, corporation finance and the theory of investment. The American economic review, 48(3), pp.261-297.

16. Pang, X., 2013. Research on financing efficiency of Ankang small and medium sized enterprises based on fuzzy comprehensive evaluation method. Modern management science, (8).

17. Qi, Z., 2013. Research On Financing Efficiency Of Listed Companies In China. Undergraduate. Tianjin University of Finance and Economics.

18. Song, W., 1997. Rational thinking on the current financing situation. Reform and strategy, (06), pp.16.

19. Wen, H., 1999. Financing preference and financing efficiency -- An Empirical Study of Listed Companies in China. Contemporary economic science, (06), pp.38-43.

20. Wen, Y., and Tang, X., 2014. A comparative study on the financing efficiency of capital markets between China and the United States. China Science and Technology Forum, (12), pp.147-153.

21. Xia, L. and Li, Y., 2011. Financing situation and reason analysis of new energy industry. Journal of Chongqing University of science and technology, 21, pp.68-69. 
22. Xia, L. and Li, Y., 2011. Financing situation and reason analysis of new energy industry. Journal of Chongqing University of science and technology, (21), pp.68-69.

23. Xiao, Y. and Guo, X., 2018. Evaluation on equity financing efficiency of new third board high tech Enterprises. Accounting Monthly, (11), pp.57-61.

24. Xiong, Z., Ding, L. and Wan, J., 2014. Measurement and promotion strategy of equity financing efficiency of Listed Companies in cultural industry. Economic management, 36(08), pp.109-116.
25. Yu, Y., Lv, H. and Li, M., 2020. The choice of tax policy for new energy automobile industry. International Taxation, pp.73-76.

26. Zeng, k., 1993. How to treat direct financing and indirect financing. Financial research, (10), pp.2126.

27. Zheng, R., 2004. Comparative analysis on financing structure of Chinese and foreign enterprises. Accounting Research, 07, pp.67-71. 